\title{
Impact of COVID-19 in residency in Oral and Maxillofacial Surgery of the Federal District Public Health System
}

\author{
Glaucia Nize Martins Santos*; Helbert Eustáquio Cardoso da Silva**; Hugo César Pinto Caracas***; \\ Nilce de Santos Melo $* * * *$
}

* PhD Student, Base Hospital Institute of the Federal District, Dentistry Department, Faculty of Health Science, University of Brasilia

** PhD Student, Dentistry Department, Faculty of Health Science, University of Brasilia

*** $\mathrm{PhD}$, Professor of Orthodontics at the Base Hospital Institute of the Federal District, Brasilia

**** PhD, Professor of Stomatology, Dentistry Department, Faculty of Health Science, University of Brasilia

Received: 12/23/2020. Approved: 02/10/2021.

\begin{abstract}
With the social isolation resulting from the coronavirus pandemic, the residency in Oral and Maxillofacial Surgery of the Federal District Public Health System adapted to maintain the attendance and course schedule. Theoretical classes migrated to online and there was an abrupt change in practical activities, such as the reduction in elective care and new biosafety protocols. The objective of this research was to understand the impact of the pandemic on the residency, including the analysis of perception and the level of satisfaction of the participants regarding online classes and practical activities, analysis of the number and type of surgeries performed in 2020 and residents' attitudes aimed for professional career, through Likert type questionnaires. Only half of the tutors and less than half of the residents were motivated to use the virtual teaching environment. In addition, the number of surgeries was reduced by more than $40 \%$. In addition, half of the residents responded that they do not feel capable to resolve unexpected events related to their training and that they are not confident in making decisions regarding their professional career. COVID-19 will continue to have a greater impact on surgical practice, so hospitals should develop a detailed contingency plan, including for pandemics and schools should permanently incorporate options of complementary remote activities in their curriculum.

Descriptors: Education; Dentistry; Surgery, Oral; Coronavirus Infections; Internship and Residency.
\end{abstract}




\section{INTRODUCTION}

The Severe Acute Respiratory Syndrome Coronavirus 2 (SARS-CoV-2) pandemic was officially acknowledged by World Health Organization in March 11, 2020 ${ }^{1}$. Since then, it was determined the total closure of non-essential activities and social isolation by the government of the Federal District, Brazil, and surroundings ${ }^{2}$.

It is a consensus that the dental category is unmatched exposed to coronavirus due to its performance in contact with potentially contaminated secretions. Therefore, most dental offices closed during the beginning of the pandemic. Specially, Oral and Maxillofacial Surgeons were exposed, since many of them provide service in the emergency room of hospitals ${ }^{3}$.

The Public Health System provides nowadays the only Oral and Maxillofacial Residency program in Federal District, a county of Brazil which counts with more than three million inhabitants. This residency was founded in 2005 and rotates in different public hospitals with tertiary level of care, including outpatient and emergency cares, with emphasis in facial traumatology. At that time, the program was composed of nine residents and five specialist preceptors.

The pandemic and quarantine determined impacts in the residency activities both in the educational aspect and in the clinical care ${ }^{4}$. Faceto-face classes were replaced by online courses and the number of elective surgeries decreased. In addition, patients screening, team dressing and surgical rooms were also adapted, so that the health of professionals and patients could be preserved $^{5}$.

Therefore, this study aims to understand the impact of COVID-19 pandemic in teaching residency in Oral and Maxillofacial Surgery, including staffs' and residents' perceptions and level of satisfaction with theoretical online classes and practical activities, and analysis of the number and type of surgical procedures carried out in 2020 compared to the same period last year and residents' attitudes towards their career.

\section{METHODS}

This study was approved by the Ethics Committee of the Base Hospital Institute of the Federal District under the number CAAE 38482620.6.0000.8153.

In order to verify if the changes in the methodologic teaching during quarantine were positives and if they should be turned permanents, an observational prospective crosssectional study was designed. After the assignment of the consent term, validated Likert questionnaires adapted from Holanda ${ }^{6}$ were answered via Google Forms, from November to December 2020, by three preceptors and nine residents covering the following aspects: a) assessment of online classes, regarding interaction and stimuli; b) attitudes, that is, interest and motivation to teach/ learn; c) dedication, discipline and time management to online education. Furthermore, a self-efficacy validated Likert survey based on Bandura's work $^{7}$ and proposed by Polydoro ${ }^{8}$ was provided to the students in order to evaluate their attitudes towards organization and execution actions required to achieve a goal.

A concept was applied to each of the criteria mentioned as follows: 1- Very suitable; 2- Suitable; 3- Indifferent; 4- Poorly suitable; 5Unsuitable. To assess the average and the standard deviation of the concepts, the following values were assigned: 1 to concept $1 ; 0,75$ to concept $2 ; 0,50$ to concept $3 ; 0,25$ to concept 4 ; and 0 to concept 5 .

Moreover, information describing the number and type of surgical procedures was retrieved from March to July 2019 and compared 
with the same period of 2020

\section{RESULTS}

In March 2020, institutional policies from the regulatory education board was sent to all residency programs with the following recommendations: theoretical classes must shift to the online method, all scientific events should be suspended, knowledge and constant updates about coronavirus disease should be available in online classes, staff over 60 years or staff and students with any risk factor should be taken away from their activities. Since then, four out of five preceptors started online theoretical classes to nine Oral and Maxillofacial residents. The residents' group consisted of six men and three women, with an average age of 22 years old, and average graduation completion time of two years. The staff was composed of three men, with an average age of 44 years old. Additional recommendations consisted of emphasis on the new protocols for dressing and de-dressing, as well as the risk classification of emergency room patients.

Since April 2020, the biggest hospitals of the Federal District were totally dedicated to COVID-19 patients. Although residents kept on rotating, elective surgeries were suspended and the main care was focused to inpatients and emergency patients. Also, a high number of contaminated people came from the penitentiaries, where the coronavirus disease rapidly disseminated.

Although all the protocols were strictly followed, three of four preceptors and seven of nine residents were soon contaminated. The first COVID-19 outbreak in Brasília was in May 20, 2020, with 5,161 new cases only that day ${ }^{9}$. Due to it and the dissatisfaction with the online method, mainly by residents, in a month and half online classes were shifted to face-to-face classes again. Courses were taken only by three preceptors because one of them was hospitalized for a long time due to coronavirus disease. Unfortunately, shortly after his recovery, he committed self-extermination.

Three leading online platforms were used: Zoom $^{\mathrm{TM}}$, Google Meet ${ }^{\mathrm{TM}}$ and Microsoft Teams $^{\mathrm{TM}}$. Most preceptors and residents agreed that the access to online platforms was easy, and that the virtual environment proposes learning situations. Residents and preceptors also agreed that complementary activities on the content, such as online texts and webinars would be useful. Moreover, most residents seemed to access classes with the proposed regularity and were satisfied, as well as staff, with the use of email, chat, forum or phone call to answer questions about the content. Besides, only half of the preceptors and less than half of the residents were motivated to use the virtual learning environment, although most of the preceptors judged their ability to teach using online platforms suitable. Almost all preceptors asserted that they have very convenient time organization for online course activities while less than half of the residents could not organize their time properly.

The practical activities maintained the same schedule as last year, however, less complex procedures were done in the same period of 2020, which hindered professional training. It was observed that no orthognatic surgery was done during March to August, 2020, and there was a significantly increase in the amount of abscess drainage while the amount of mandible fractures surgery decreased. The total surgical procedures had a decrease of more than $40 \%$. According to the questionnaires, half of the residents are satisfied with the workload of practical activities, although most of them judged that the practical activities carried out during the pandemic were insufficient for their professional training. In comparison, all preceptors think that 
the workload for practical activities is suitable and only half of them agree that the practical activities during the pandemic were harmed.

Tables 1 and 2 show detailed residents and staff perceptions of online classes and satisfaction with practical activities, respectively. Table 3 shows a comparison of the procedures done in 2019 and in the same period of 2020.

Table 1. Residents' perceptions of online classes and satisfaction with practical activities

\begin{tabular}{lcc}
\hline Interaction and Stimulus & Average & SD* $^{*}$ \\
\hline a. Does the virtual environment facilitate interaction and interest in the subject? & 0,305 & 0,166 \\
b. Does the virtual environment propose learning situations? & 0,472 & 0,291 \\
c. Are online activities relevant and meet the proposed objectives? & 0,444 & 0,300 \\
d. Was access to online platforms easy? & 0,527 & 0,458 \\
e. Does the online tool instigate change in behavior and attitude? & 0,444 & 0,370
\end{tabular}

\section{Interest and motivation}

f. Are you motivated to use the virtual learning environment?

$0,361 \quad 0,253$

g. Was carrying out complementary activities on the content (video, lectures by other teachers, scientific articles, webinars) useful?

h. How do you judge your ability to study using the virtual learning environment?

$0,444 \quad 0,300$

\begin{tabular}{lll}
\hline Dedication, discipline and time management & & \\
\hline i. How do you judge your time organization for online course activities? & 0,416 & 0,279 \\
j. How do you judge your self- discipline for online teaching? & 0,388 & 0,220 \\
k. Do you access classes with the proposed regularity? & 0,666 & 0,176
\end{tabular}

\section{Communication tools}

1. Does the environment trigger the exchange of information with colleagues and teachers?

$0,305 \quad 0,300$

$\mathrm{m}$. Are the links provided relevant to the content for learning?

0,416

n. How do you judge using e-mail, chat, forum or phone call to answer questions about the content?

$0,472 \quad 0,363$

\section{Satisfaction with the practical activities of the residency}

o. How do you judge the workload for practical activities in oral and maxillofacial surgery?

p. How do you judge the practical activities carried out during the pandemic for your professional training? 
Table 2. Preceptors' perceptions of online classes and satisfaction with practical activities

\begin{tabular}{llc}
\hline Interaction and Stimulus & Average & SD $^{*}$ \\
\hline $\begin{array}{l}\text { a. Does the virtual environment facilitate interaction and interest in the } \\
\text { subject? }\end{array}$ & 0,416 & 0,381 \\
$\begin{array}{l}\text { b. Does the virtual environment propose learning situations? } \\
\text { c. Are online activities relevant and meet the proposed objectives? }\end{array}$ & 0,583 & 0,520 \\
$\begin{array}{l}\text { d. Was access to online platforms easy? } \\
\text { e. Does the online tool instigate change in behavior and attitude? }\end{array}$ & 0,633 & 0,577 \\
\hline Interest and motivation & 0,416 & 0,381 \\
\hline f. Are you motivated to use the virtual learning environment? & 0,500 & 0,433 \\
g. Was carrying out complementary activities on the content (video, lectures & 0,583 & 0,520 \\
by other teachers, scientific articles, webinars) useful? & & \\
h. How do you judge your ability to teach using the virtual learning & 0,666 & 0,577 \\
environment? & &
\end{tabular}

\section{Dedication, discipline and time management}

\begin{tabular}{lll}
\hline i. How do you judge your time organization for online course activities? & 0,916 & 0,144
\end{tabular}

\begin{tabular}{l}
\hline Communication tools \\
$\begin{array}{l}\text { j. Does the environment trigger the exchange of information with the } \\
\text { students? } \\
\text { k. How do you judge the use of e-mail, chat, forum or phone call to answer } \\
\text { questions about the content? }\end{array} \quad 0,500 \quad 0,520$
\end{tabular}

Satisfaction with the practical activities of the residency
$\begin{aligned} & \text { l. How do you judge the workload for practical activities in oral and } \\ & \text { maxillofacial surgery? }\end{aligned}$
$\begin{aligned} & \text { m. How do you judge the practical activities carried out during the pandemic } \\ & \text { for the professional training of residents? }\end{aligned}$

Statistics based on three preceptors' responses. *SD = Standard Deviation 
Table 3. Comparison of procedures in the years 2019 and 2020

\begin{tabular}{|c|c|c|c|}
\hline \multicolumn{2}{|c|}{ March - August, 2019} & \multicolumn{2}{|c|}{ March - August, 2020} \\
\hline \multicolumn{2}{|c|}{ Elective surgeries: } & \multicolumn{2}{|c|}{ Elective surgeries: } \\
\hline Orthognatic & $31 \%$ & Mandibular fracture & $36.6 \%$ \\
\hline $\mathrm{ZMC}^{*}$ and orbital fracture & $16.67 \%$ & Lesion exeresis & $12.2 \%$ \\
\hline Mandibular reconstruction & $13.1 \%$ & $\mathrm{ZMC}^{*}$ and orbital fracture & $12.2 \%$ \\
\hline Lesion exeresis & $12 \%$ & Removal of synthesis materials & $7.3 \%$ \\
\hline Mandibular fracture & $10.7 \%$ & Frontal bone fracture & $7.3 \%$ \\
\hline Le Fort I & $3.6 \%$ & Mandibular reconstruction & $4.9 \%$ \\
\hline Condylectomy & $3.6 \%$ & Panfacial fractures & $4.9 \%$ \\
\hline Discopexy & $2.4 \%$ & Le Fort I & $4.9 \%$ \\
\hline ATM prothesis & $1.155 \%$ & Le Fort III & $2.425 \%$ \\
\hline Le Fort III & $1.155 \%$ & Condylectomy & $2.425 \%$ \\
\hline Foreign body removal & $1.155 \%$ & Maxilary expansion & $2.425 \%$ \\
\hline Eminectomy & $1.155 \%$ & & \\
\hline Non-specified & $1.155 \%$ & & \\
\hline Total & 84 & Total & 41 \\
\hline \multicolumn{2}{|c|}{ Emergency surgeries } & \multicolumn{2}{|c|}{ Emergency surgeries } \\
\hline Mandibular fracture & $80.3 \%$ & Mandibular fracture & $57.45 \%$ \\
\hline Abscess drainage & $6.06 \%$ & Abscess drainage & $31.9 \%$ \\
\hline $\mathrm{ZMC} *$ fracture & $4.54 \%$ & $\mathrm{ZMC} *$ fracture & $6.4 \%$ \\
\hline Face and mouth suture & $3.03 \%$ & Removal of synthesis materials & $2.125 \%$ \\
\hline Panfacial fractures & $3.03 \%$ & Panfacial fractures & $2.125 \%$ \\
\hline Maxilary fracture & $1.52 \%$ & & \\
\hline Palate debridement & $1.52 \%$ & & \\
\hline Total & 66 & Total & 47 \\
\hline
\end{tabular}

*ZMC: zygomatic-maxillary complex

The self-efficacy survey showed that residents are not sure to make decisions related to their academic training and still doubt which area to pursue. Also, most of them had difficulties using cognitive strategies to facilitate learning, while half of them could not understand the course content. Half of the participants answered that they could not solve unexpected events related to their training in pandemic time. Less than half of the students seek help from preceptors to develop course activities while most of them can establish friendships with classmates and ask for help from colleagues. Almost all of the students showed motivation and effort to academic activities although less than half seek information about the institution's 
resources or programs. Table 4 shows detailed results from the self-efficacy survey.

Table 4. Students' self-efficacy survey

\begin{tabular}{|c|c|c|}
\hline ACADEMIC SELF-EFFICACY how much I am capable of... & Average & SD* \\
\hline 1. Learn the content that is necessary for my training? & 0,527 & 0,422 \\
\hline 2. Use cognitive strategies (making summaries, spreadsheets, diagrams) to facilitate my learning? & 0,472 & 0,384 \\
\hline 3. Demonstrate, during the assessment, what I learned during my course? & 0,527 & 0,317 \\
\hline 4. Understand my course requirements? & 0,583 & 0,414 \\
\hline 5. Apply the knowledge learned in the course in practical situations? & 0,611 & 0,416 \\
\hline 6. Establish conditions for the development of the work requested by the course? & 0,555 & 0,390 \\
\hline 7. Understand the content covered in the course? & 0,500 & 0,375 \\
\hline $\begin{array}{l}\text { 8. Cumprir o desempenho exigido para aprovação no curso? } \\
\text { meet the performance required to pass the course? }\end{array}$ & 0,555 & 0,370 \\
\hline 9. Prepare for the assessments? & 0,527 & 0,291 \\
\hline \multicolumn{3}{|l|}{ SELF-EFFICACY IN REGULATING TRAINING } \\
\hline 10. Plan actions to achieve my professional goals? & 0,583 & 0,353 \\
\hline 11. Reflect on the achievement of my training goals? & 0,583 & 0,306 \\
\hline 12. Select, among the resources offered by the institution, the most appropriate for my training? & 0,500 & 0,330 \\
\hline 13. Make decisions related to my training? & 0,472 & 0,422 \\
\hline $\begin{array}{l}\text { 14. Define, with certainty, what I intend to follow among the various possibilities of professional } \\
\text { activity that exist in my area of training? }\end{array}$ & 0,388 & 0,397 \\
\hline 15. Establish my professional goals? & 0,416 & 0,395 \\
\hline 16. Solve unexpected problems related to my training? & 0,500 & 0,330 \\
\hline \multicolumn{3}{|l|}{ SELF-EFFICACY IN PROACTIVE ACTIONS } \\
\hline 17. Keep me updated on new professional trends in my training area? & 0,555 & 0,325 \\
\hline 18. Seek help from teachers for the development of course activities? & 0,444 & 0,390 \\
\hline 19. Contribute ideas to improve my course? & 0,555 & 0,273 \\
\hline 20. Update the knowledge acquired in the course? & 0,527 & 0,363 \\
\hline 21. Seize opportunities to participate in extracurricular activities? & 0,500 & 0,375 \\
\hline 22. Seek information about the resources or programs offered by my institution? & 0,444 & 0,273 \\
\hline 23. Claim extracurricular activities relevant to my training? & 0,555 & 0,325 \\
\hline 24. Express my opinion when another classmate disagrees with me? & 0,555 & 0,300 \\
\hline 25. Ask for help, when necessary, from colleagues in the course activities? & 0,611 & 0,377 \\
\hline 26. Work in a group? & 0,527 & 0,341 \\
\hline 27. Cooperate with colleagues in course activities? & 0,611 & 0,356 \\
\hline 28. Establish good relationship with my teachers? & 0,666 & 0,395 \\
\hline 29. Ask when I am in doubt? & 0,611 & 0,333 \\
\hline 30. Establish friendships with classmates? & 0,666 & 0,353 \\
\hline 31. Strieve for academic activities? & 0,694 & 0,370 \\
\hline 32. Motivate me to do the activities related to the course? & 0,694 & 0,300 \\
\hline 33. Finish course work on time? & 0,500 & 0,375 \\
\hline 34. Plan to carry out the activities requested by the course? & 0,611 & 0,333 \\
\hline
\end{tabular}

Statistics based on nine residents' responses. *SD $=$ Standard Deviation

\section{DISCUSSION}

COVID-19 is disrupting routines in hospitals and health schools. As such, it is essential to record and study the full extent of the changes in education being made in response to this international emergency to clarify how to recover from this pandemic ${ }^{10}$.

In the theoretical context, presential 
conferences, congresses and meetings have been cancelled or postponed, further reducing the opportunities for trainees' continuous education. On the other hand, virtual platforms allowed the implementation of online lectures and teaching sessions ${ }^{11-14}$. The curricular reforms undertaken by many academic institutions worldwide in the past decade, mainly promoting flippedclassrooms and active learning, have facilitated an easy transition of face-to-face learning to the online method ${ }^{12,13,15-18}$. However, although the described residency has turned to flippedclassroom for a long time, Oral and Maxillofacial residents did not adapt to the synchronous online classes during the pandemic. Even though flipped-classrooms for Maxillofacial Surgery training have been discussed previously, further research is required regarding virtual learning ${ }^{19,20}$. Other asynchronous modalities of online education described in the literature, such as reports and case discussions, online journal articles, webinars for interdisciplinary learning and videos, were well accepted by the interviewed residents. Technology can be very useful ${ }^{21}$ but, for many preceptors and residents, it still involves a learning curve. The Remote Emergency Teaching ${ }^{22}$ imposed by the pandemic made impossible to evaluate and choose between synchronous and asynchronous online teaching and learning, to relay to students distance education protocols, yet still keeping the original plan of content delivery. The success of elearning depends on the attitudes and interactive teaching styles of the staff, as well as on the experience and attitudes of students concerning technology $y^{23,24}$. In this study, the theoretical content of the 2020 year was all completed, with online and face-to-face classes.

The COVID-19 pandemic will continue to have a major impact on surgical practice. The first activity suspended under the state of emergency in teaching hospitals was dental residents' elective procedures. To postpone direct patient care is the biggest challenge, since it is the key component of the dental curriculum ${ }^{25}$. No virtual sessions can duplicate the close experience with patients and surgery can only be perfected by practicing ${ }^{14,23,26}$. Furthermore, it is unclear whether and when the service will be ready to resume elective surgical cases ${ }^{27}$. There is a possibility that surgical education may hinder and inevitably reduce students' interest in pursuing a surgical career ${ }^{26}$. Indeed, there has been declining interest in surgery among United Kingdom medical students ${ }^{28}$, and this pandemic may serve to hasten this trend. The elective cases for benign disease that are mostly affected are the ones that residents usually performed with minimal supervision, in contrast to the more complex urgent or life-threatening operations that staff mostly perform. ${ }^{29}$ The residents were most concerned with losing experience in anesthesia, orthognathic surgery, and reconstructive and cosmetic surgery ${ }^{30}$, which is in agreement with the findings of this study. Implementing technology into health education may allow students to develop collaborative skills and improve adaptability. Use of remotetechnologies and augmented reality, whereby residents can witness live proctoring by surgeons and interact remotely, can help surgical training with an immersive experience ${ }^{10,14,26,31}$.

Still in learning the period, residents must correlate their academic training with their valuable contribution to the current health crisis. Students who can better adapt to this adverse event usually show more creativity and innovation to alter pre-conceived notions of how patient care should be practice. In fact, residents can show new methods for developing their skills, teamwork and dedication to research. Regardless of each student's situation's nuances, all of them will face difficulties due to the widespread effects of the COVID-19 
pandemic ${ }^{10}$. At the time of submission, 9,339,420 cases of COVID-19 in Brazil with 227,563 deaths and $104,499,482$ cases around the world with 2,271,232 deaths had been reported ${ }^{32}$.

\section{CONCLUSION}

According to the protocols imposed on the residency program as a result of the pandemic, it is certain that residents have lost many activities, such as congresses, meetings and theoretical classes. Also, many residents and preceptors had to leave their daily routine for at least fourteen days to recover from SARS-CoV2 infection.

Although preceptors and residents agreed that using online platforms was easy, both were not motivated enough to use the virtual learning environment. Most of the residents were dissatisfied with the online method, and preceptors soon returned to face-to-face courses. Therefore, webinars and other online contents were used only as complementary activities. In 2020, the total number of surgical procedures decreased by more than $40 \%$ and less complex procedures were performed, which hindered professional training. Thus, the majority of residents considered that the practical activities carried out during the pandemic were insufficient for their professional training while all preceptors thought that the workload for practical activities is suitable and only half of them agreed that the practical activities during the pandemic were harmed. In addition, the self-efficacy survey showed that residents are not sure to make decisions related to their academic training and most of them had difficulties using cognitive strategies to facilitate learning.

Moving forward, it will be important to systematically study the effects of the changes on both residents and program training, including residents' career progression, their mental health and biosafety of the team.

\section{RESUMO}

Impacto da COVID-19 na residência em Cirurgia Buco-Maxilo-Facial da Secretaria de Saúde do Distrito Federal

Com o isolamento social decorrente da pandemia de coronavírus, a residência em Cirurgia BucoMaxilo-Facial da Secretaria de Saúde do Distrito Federal se adaptou para manter o atendimento e o cronograma do curso. Aulas teóricas migraram para online e houve abrupta mudança das atividades práticas, como a diminuição do atendimento eletivo e novos protocolos de biossegurança. O objetivo dessa pesquisa foi entender o impacto da pandemia no ensino na residência, incluindo a análise de percepção e do nível de satisfação dos participantes quanto às aulas online e atividades práticas, análise do número e tipo de cirurgias realizadas em 2020 e atitudes dos residentes voltadas para carreira profissional, por meio de questionários do tipo Likert. Apenas metade dos preceptores e menos da metade dos residentes estavam motivados a usar o ambiente virtual de ensino. O número de cirurgias foi reduzido em mais de $40 \%$. Além disso, metade dos residentes respondeu que não se sente capaz de resolver eventos inesperados relacionados à sua formação e que não está segura em tomar decisões relativas à sua carreira profissional. A COVID-19 continuará a ter maior impacto na prática cirúrgica, por isso, hospitais devem desenvolver um plano de contingência detalhado, inclusive para o caso de futuras pandemias e escolas devem incorporar opções de atividades remotas complementares permanentemente em seu currículo.

Descritores: Educação; Odontologia; Cirurgia Bucal; Infecções por Coronavírus; Internato e Residência.

\section{REFERENCES}

1. World Health Organization [Internet]. USA: World Health Organization; c2020 [cited 2020, Dec 1] WHO Director-General's opening remarks at the media briefing on COVID-19. Available from: 
https://www.who.int/director-general/speec hes/detail/who-director-general-s-openingremarks-at-the-media-briefing-on-covid-19--11-march-2020.

2. Brasil. Decreto $\mathrm{n}^{\circ} 40.539$, de 19 de março de 2020. Dispõe sobre as medidas para enfrentamento da emergência de saúde pública de importância internacional decorrente do novo coronavírus e dá outras providências. [Internet]. Diário Oficial do Distrito Federal edição extra n ${ }^{0} 36$. Seção 1. 2020 mar.19 [acesso em 2020 nov 18]. Disponível em: http://www.sinj.df. gov.br/sinj/Norma/ac087b76d5f34e38a5cf3 573698393f6/Decreto_40539_19_03_2020. html.

3. Brasil. Ministério da Saúde. Nota Técnica ${ }^{\circ}$ 9/2020-CGSB/DESF/SAPS/MS. Assunto COVID-19 e Atendimento Odontológico no SUS. [Internet]. CRO SP 2020 mar. [acesso em 2020 nov 22]. Disponível em: http://www.crosp.org.br/uploads/arquivo/ab 69d79b87d04780af08a70d8cee9d70.pdf.

4. Chick RC, Clifton GT, Peace KM, Propper BW, Hale DF, Alseidi AA, et al. Using Technology to Maintain the Education of Residents During the COVID-19 Pandemic. J Surg Educ. 2020; Jul-Aug;77(4):729-32.

5. Evans DJ, Bay BH, Wilson TD, Smith CF, Lachman N, Pawlina W. Going virtual to support anatomy education: A stop gap in the midst of the COVID-19 pandemic. Anat Sci Educ. 2020;13:279-83.

6. Holanda VR de. Hipermídia educacional para o ensino das doenças sexualmente transmissíveis: construção, validação e avaliação [Tese]. Fortaleza: Universidade Federal do Ceará; 2014.

7. Bandura A. Self-efficacy, the exercise of control. New York: Freeman and Company; 1997.

8. Polydoro SAJ, Guerreiro-Casanova DC.
Escala de Auto-eficácia na formação superior: construção e estudo de validação. Aval. psicol. 2010 Ago;9( 2 ): 267-78.

9. News.google.com/covid19/map [Internet]. Brasil: Google Notícias; c2020. [cited 2020 Dec 23]. Available from: https://news. google.com/covid19/map?hl=pt-BR\&gl= BR\&ceid=BR\%3Apt -419 .

10. Ferrel MN, Ryan JJ. The Impact of COVID19 on Medical Education. Cureus [Internet]. 2020 Mar 31 [cited 2020 Dec 17];12(3). Available from: https://pubmed. ncbi.nlm.nih.gov/32368424/.

11. Gallo G, Trompetto M. The Effects of COVID-19 on Academic Activities and Surgical Education in Italy [Internet]. Vol. 33, Journal of Investigative Surgery. Taylor and Francis Ltd.; 2020 [cited 2020 Dec 18]. p. 687-9. Available from: https:// pubmed.ncbi.nlm.nih.gov/32249660/.

12. Moszkowicz D, Duboc H, Dubertret C, Roux D, Bretagnol F. Daily medical education for confined students during coronavirus disease 2019 pandemic: A simple videoconference solution. Clin Anat [Internet]. 2020 Sep 1 [cited 2020 Dec 18];33(6):927-8. Available from: https:// pubmed.ncbi.nlm.nih.gov/32253771/.

13. Woolliscroft JO. Innovation in response to the COVID-19 pandemic crisis. Vol. 95, Academic Medicine. Lippincott Williams and Wilkins; 2020. p. 1140-2.

14. Dedeilia A, Sotiropoulos MG, Hanrahan JG, Janga D, Dedeilias P, Sideris M. Medical and Surgical Education Challenges and Innovations in the COVID-19 Era: A Systematic Review. In Vivo. 2020 Jun;34(3 Suppl):1603-11.

15. Rose S. Medical Student Education in the Time of COVID-19. J Am Med Assoc. 2020 Jun 2;323(21):2131-2.

16. Ramnanan C, Pound L. Advances in medical 
education and practice: student perceptions of the flipped classroom. Adv Med Educ Pract. 2017 Jan;8:63-73.

17. Liebert CA, Mazer L, Bereknyei Merrell S, Lin DT, Lau JN. Student perceptions of a simulation-based flipped classroom for the surgery clerkship: A mixed-methods study. In: Surgery (United States) [Internet]. Mosby Inc.; 2016 [cited 2020 Dec 18]. p. 591-8. Available from: https:// pubmed.ncbi.nlm.nih.gov/27262534/.

18. Gianoni-Capenakas S, Lagravere M, Pacheco-Pereira C, Yacyshyn J. Effectiveness and Perceptions of Flipped Learning Model in Dental Education: A Systematic Review. J Dent Educ [Internet]. 2019 Aug [cited 2020 Dec 18];83(8):935-45. Available from: https://pubmed. ncbi.nlm.nih.gov/31133621/.

19. Elledge R, Houlton S, Hackett S, Evans MJ. "Flipped classrooms" in training in maxillofacial surgery: preparation before the traditional didactic lecture? $\mathrm{Br} \mathrm{J}$ Oral Maxillofac Surg. 2018 Jun 1;56(5):384-7.

20. Carlson ER. COVID-19 and Educational Engagement. J Oral Maxillofac Surg [Internet]. 2020 Jul 1 [cited 2020 Dec 18];78(7):1049-51. Available from: https:// pubmed.ncbi.nlm.nih.gov/32371146/.

21. Santos GNM, Leite AF, De Figueiredo PTS, Pimentel NM, Flores-Mir C, De Melo NS, et al. Effectiveness of E-learning in oral radiology education: A systematic review. $\mathbf{J}$ Dent Educ. 2016;80(9):1126-39.

22. Hodges CB, Moore S, Lockee BB, Trust T, Bond MA. The Difference Between Emergency Remote Teaching and Online Learning. Educause Review. 2020;1-14.

23. Iyer P, Aziz K, Ojcius DM. Impact of COVID-19 on dental education in the United States. J Dent Educ [Internet]. 2020 Jun 1 [cited 2020 Dec 17];84(6):718-22. Available from: https://pubmed.ncbi.nlm.nih.gov/ 32342516/.

24. Webster J, Hackley P. Teaching effectiveness in technology-mediated distance learning. Acad Manag J. 1997;40(6):1282-309.

25. Iyer P, Aziz K, Ojcius DM. Impact of COVID-19 on dental education in the United States. J Dent Educ. 2020 Jun;84(6):718-22.

26. Khan S, Mian A. Medical education: COVID-19 and surgery [Internet]. Vol. 107, British Journal of Surgery. John Wiley and Sons Ltd; 2020 [cited 2020 Dec 17]. p. e269. Available from: https://pubmed.ncbi. nlm.nih.gov/32492170/.

27. Huntley RE, Ludwig DC, Dillon JK. Early Effects of COVID-19 on Oral and Maxillofacial Surgery Residency Training-Results From a National Survey. J Oral Maxillofac Surg [Internet]. 2020 Aug 1 [cited 2020 Dec 17];78(8):1257-67. Available from: https://pubmed.ncbi. nlm.nih.gov/32536436/.

28. Moberly T. Specialty training vacancies increase by $30 \%$ in a year. BMJ. 2017;(318):j3410.

29. Porpiglia F, Checcucci E, Amparore D, Verri P, Campi R, Claps F, et al. Slowdown of urology residents' learning curve during the COVID-19 emergency. BJU Int [Internet]. 2020 Jun 1 [cited 2020 Dec 18];125(6):E15-7. Available from: https:// pubmed.ncbi.nlm.nih.gov/32274879/.

30. Panesar K, Dodson T, Lynch J, Bryson-Cahn C, Chew L, Dillon J. Evolution of COVID19 Guidelines for University of Washington Oral and Maxillofacial Surgery Patient Care. J Oral Maxillofac Surg [Internet]. 2020 Jul 1 [cited 2020 Dec 18];78(7):1136-46. Available from: https://pubmed.ncbi. nlm.nih.gov/32389541/.

31. Greenfield MJ, Luck J, Billingsley ML, 
Heyes R, Smith OJ, Mosahebi A, et al. Demonstration of the effectiveness of augmented reality telesurgery in complex hand reconstruction in Gaza. Plast Reconstr Surg [Internet]. 2018 [cited 2020 Dec 18];6(3). Available from: https://pubmed. ncbi.nlm.nih.gov/29707463/.

32. Map@Coronavirus.Jhu.Edu [Internet]. USA: Coronavirus COVID-19 Global Cases by the Johns Hopkins university; c2020 [cited 2020 Dec 23]. Available from: https://coronavirus.jhu.edu/map.html.

\section{Correspondence to:}

Glaucia Nize Martins Santos e-mail: nize.gal@gmail.com QI 31 lote 8 apt 702B Guará II 71065-912 Brasília/DF, Brazil 